Journal of the Society for the Study of Architecture in Canada

Le Journal de la Société pour l'étude de l'architecture au Canada

\title{
Astronomer Mary Grey and the Architecture of Canada's Dominion Observatory
}

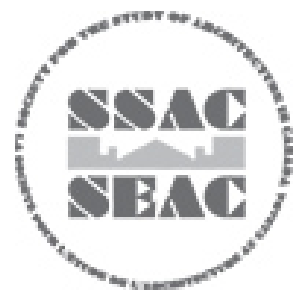

\section{Sharon Odell}

Volume 45, numéro 1, 2020

URI : https://id.erudit.org/iderudit/1075073ar

DOI : https://doi.org/10.7202/1075073ar

Aller au sommaire du numéro

Éditeur(s)

SSAC-SEAC

ISSN

2563-8696 (numérique)

Découvrir la revue

Citer cet article

Odell, S. (2020). Astronomer Mary Grey and the Architecture of Canada's Dominion Observatory. Journal of the Society for the Study of Architecture in Canada / Le Journal de la Société pour l'étude de l'architecture au Canada, 45(1), 10-21. https://doi.org/10.7202/1075073ar 


\section{ASTRONOMER MARY GREY AND THE ARCHITECTURE OF CANADA'S DOMINION OBSERVATORY}

SHARON ODELL has a twenty-five-year career in museology at municipal, provincial, and national level museums; as a mentor she presently sits on an Algonquin College advisory committee for Applied Museum Studies. She resides in Ottawa and holds an M.A. in Art History from Carleton University; she specializes in research on art, architecture, and the history of Canadian women in science. Her latest publication is on public landscape art of Cairn Cunnane in Render Journal 2017, and her latest co-curated exhibition at Carleton University Art Gallery was a Science Lab series titled HERbarium, 2017. In addition, she conducts annual presentations (2017-2020) on the Canadian history of scientific architecture and women in astronomy, to Canada wide audiences, as a member of the Royal Astronomical Society of Canada.

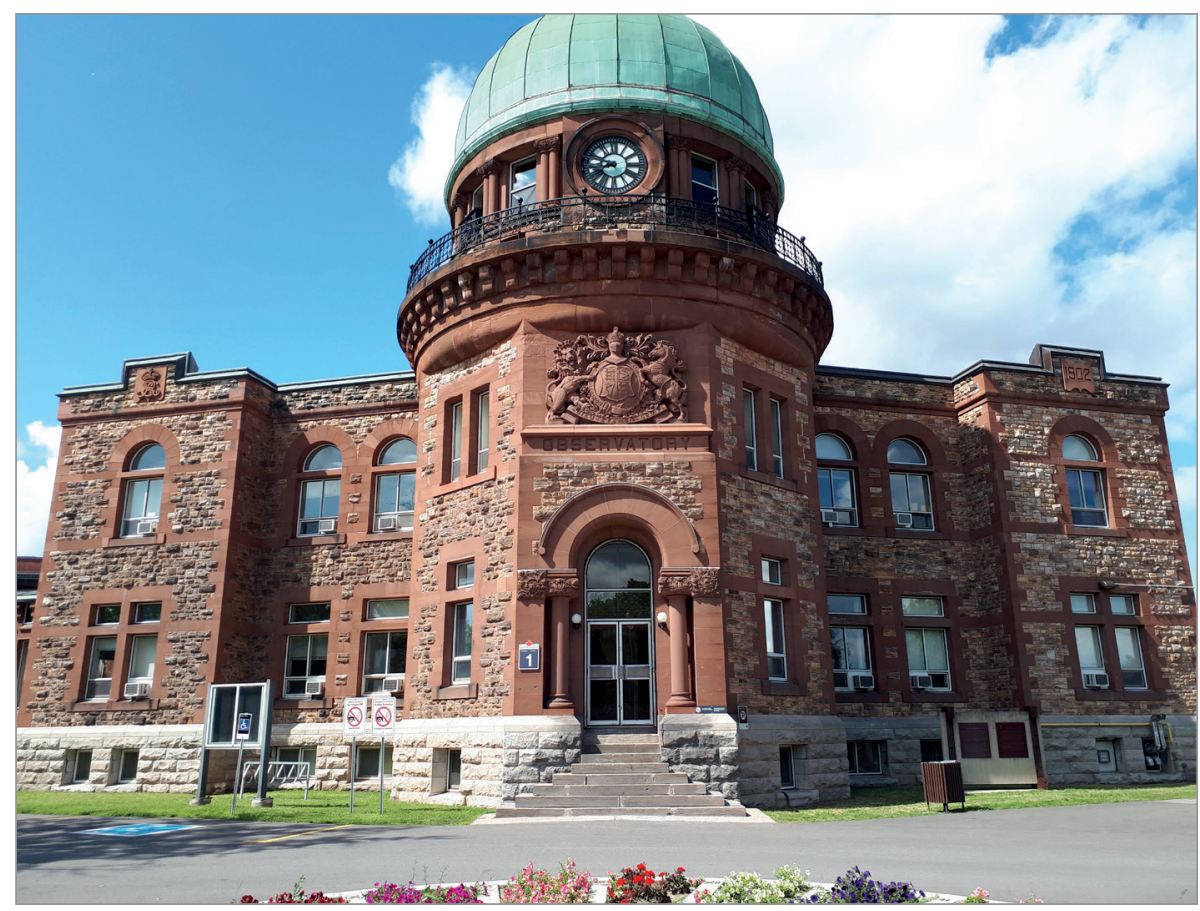

FIG. 1. DOMINION OBSERVATORY, OTTAWA, BY ARCHITECT DAVID EWART. | SHARON ODELL, AUGUST 10, 2019.
$>$ SHARON ODELL

W hen the first National Dominion Observatory of Canada opened in Ottawa, Ontario, in April of 1905, its function was to mirror that of the Royal Observatory at Greenwich and to become a Canadian institutional resource used for timekeeping, railway, and survey requirements. Built by David Ewart between 1902-1904, its architecture, an example of a blend of Romanesque Revival and Edwardian classicist styles used in North America, was meant to visually highlight the national importance of the science of astronomy within a colonized country striving for independence (fig. 1). Today, thankfully, this building's legacy has been preserved in part thanks to the keen foresight of the last self-taught astronomer who worked there, Mary Grey. Grey's curatorial work in her later museum role helped bring focus to this same architecture, which still holds layers of great significance at local, national, and international levels, advancing its cause for comparison to other observatory histories around the world. Many believe the key for this building to continue its educational value today is to strengthen its scientific heritage designation by following the same principles that Grey laid out, as this article will reveal. Specifically, these principles include her public outreach and preservation of the Observatory campus as-a-whole. Otherwise, without all parts of this story, only a fragmented lesson in Canada's history of astronomy will be known to future generations.

The late John Hodgson, who supervised Grey as director general of the Earth Physics Branch of Energy Mines and Resources (EMR) in 1979, wrote the first 
two-volume history on this Observatory, titled The Heavens Above and the Earth Beneath. ${ }^{1}$ While Hodgson's volumes recount the overall history of the building and its social past, I have chosen to study this architecture within its surrounding location of the National Historic Site of the Canadian Central Experimental Farm (the CEF), in relation to Grey's career. Also, through use of a visual analysis of the Dominion Observatory, with a focus on its heritage features, I will analyze Grey's contributions to its preservation. The objective here is to examine her as a notable astronomer, who imparted her knowledge to bringing the public's attention to the Observatory, which lent further Canadian cultural value to its scientific heritage.

\section{MARY GREY: A FIRST-CLASS} WOMAN ASTRONOMER

When examining how the Dominion Observatory became a part of Mary Grey's scientific research, it becomes clear how the building's function changed after $1970 .^{2}$ This is when it became the EMR Branch of Seismology, as the astronomy department was dissolved that same year. In addition, the life of the Observatory building after Grey's tenure was over can be traced to facilitate a discussion of her strong advocacy for the safeguarding of the tools that once encompassed her trade.

Born in 1927 in the town of Chipman, New Brunswick, Grey received her bachelor of science degree in civil engineering from the University of New Brunswick. A selftaught astronomer, her career began at the Geodetic Survey Department of Canada (GSD), from 1941 until the early 1950s. ${ }^{3}$ The main building for GSD was located beside the Dominion Observatory in Ottawa, also built by Ewart in 1914. From 1940 until 1985, the Geodetic Survey was the first-order field of astronomy that had control of the Laplace azimuths. These official geographic points are regulated by triangulation through astronomical coordinates. ${ }^{4}$ Grey likely worked at GSD for the astronomic positioning of mapping. Therefore, it was through that department that she obtained her first experience in practical astronomy; however, she has stated that her "passion for astronomy only really took off like fire after moving to the Dominion Observatory in Ottawa." ${ }^{5}$

While working at the Observatory, Grey led public and educational tours as she continued to support its preservation after leaving her astronomy career-to become a curator at the National Science and Technology Museum. As a vocal and recognized member of the Ottawa community, and as a past president of the Royal Astronomical Society of Canada, Grey successfully raised awareness of this unique building and its inherent value to Canada. She facilitated a stronger external recognition of the Observatory through the rare examples of Canada's first historical telescopes, namely the Dominion Telescope, through her support and scientific work. While doing so, she also highlighted the significance of the Observatory's unpublicized historic role in its staff for mentoring, and how these work-related opportunities enabled the first Canadian women scientists to practice physics and astronomy on a national level. Grey herself was mentored in this manner by her predecessor, Miriam Burland, who worked at the Dominion Observatory from 1928 to 1968, as well as astronomer Helen Sawyer Hogg. The latter had also worked with Burland and other astronomical staff in Ottawa, while at the Dominion Astrophysical Observatory in British Columbia, from the 1920s until 1935. As Grey became the epitomic source for historic information

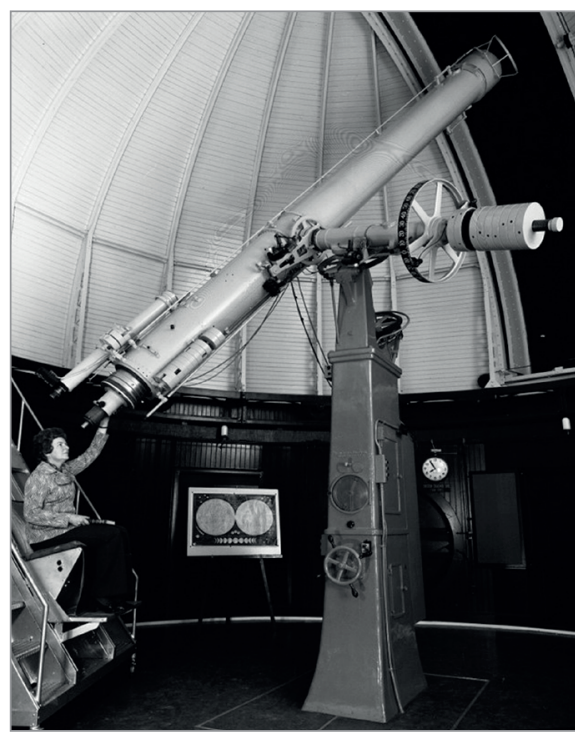

FIG. 2. MARY GREY WITH 15" REFRACTING TELESCOPE INSIDE THE DOMINION OBSERVATORY DOME, OTTAWA, C. 1962. | SLIDE 340-1, NATURAL RESOURCES CANADA, EARTH SCIENCES DEPARTMENT.

on the national Observatory following her mentors, it is here that I would like to focus more on its architectural history and related visual features. This will give more of a perspective as to why Grey and her colleagues were so motivated in promoting its scientific heritage (fig. 2).

\section{THE IDEAL LANDSCAPE FOR A NATIONAL ASTRONOMY PROGRAM: ARM OF CANADIAN PARLIAMENT}

David Ewart (1841-1921) was chosen to be the Dominion architect for many funded government buildings in Canada's capital, the city of Ottawa. Originally from Scotland, he engaged with medieval Revival modes that dominated North America in the nineteenth century, in order to create one of many new modern building styles for Canada's own legacy. He often did this to exemplify an innovative simplified form of what he thought Canada's reverent institutions could be. In the 1890s, Ewart was also the ideal 
architect to construct a national observatory. At the request of the Canadian government and Canadian renowned astronomers William King and his colleague Otto Klotz, the project was assigned to Ewart. Both astronomers would become directors of this Observatory once it was completed within the observatory crescent complex. The original space of the Cliff Observatory on Parliament Hill was limiting for its older technology and lack of space for scientific research growth. The chosen landscape for the more innovative Observatory, called the Canadian Central Experimental Farm (CEF), would be at the same place as the National Canadian Astronomy program would be newly located. A Department of Energy, Mines and Resources, it was a part of the Earth Physics Branch. Additionally, after the Observatory plans were finalized in 1902, this same section of the CEF land became known as the Natural Resources Canada (NRCAN) Observatory campus.

The creation of a campus with the ability to expand was key to the main Observatory building's function. The outer buildings to be added around the main Observatory contributed greatly toward broadening Canadian astronomical research. The expansion of azimuth building markers, the solar telescope barn, photo equatorial observatory, astronomer's house, and the fundamental long data centre buildings in side yards, allowed not only growth of the astronomy program, but also made it possible to compete with other world institutions. In addition, this site for the Observatory was chosen because of its rural area, on the outskirts of the Canadian capital, so that it could be near the nation's house of government as it was originally utilized for the timekeeping of the country; also, so that it could be close to a fault line for the seismology program, which would share the main building. Thus, it was far enough away from the city centre to avoid light pollution, and to have the building positioned at an elevation advantageously within low-lying farmland and above treelines for astronomy to take place.

It did not take long for this building to become an immediate tourist attraction of Canada's scientific pursuits; even during the construction phase, there were stereographic images and postcards of this building dating between 1902 to 1909 . Likely, the popularity of the Observatory occurred when it opened in 1905, due to the support of Prime Minister Sir Wilfred Laurier. Laurier's advocacy reinforced the idea that this Observatory was to be considered an arm of the parliamentary precinct; a building that would have remained on that central city site, as part of the parliamentary group of buildings if it were not for light pollution. At the time it was recognized as a national achievement, where the nation's time would be kept, and of what would be a symbol of Canada's progress in astronomical science, as a newly formed country. ${ }^{6}$ The architecture represented the pursuits of the people of Canada as it was built to perform practical functions for the nation. However, it also demonstrated another factor of national prestige and a nation's progress. This idea was positioned through the visual identity of the new government, also through use of large-scale architecture within an expansive landscape created by Ewart's design, and dictated by the astronomical technology of that day (1896-1902) ${ }^{7}$ (figs. 3 and 4).

\section{THE OBSERVATORY EXTERIOR: A FAÇADE FOR CANADIAN SCIENCE}

The outstanding qualities of the Observatory's design and many of its original traits remain today. The plan to build a national Observatory for Canada began in the 1890s, but looking back even further still, the famous observatory designed by Christopher Wren in 1675 Greenwich, England, inspired modern architectural ideas for a Canadian version. During the nineteenth century, British architecture was regarded as a resource for building-type examples, since Canada was presided over by England as a Dominion rather than as an independent nation. Wren's Greenwich observatory design was a fitting architectural precedent and it was completed combining his knowledge of physics and astronomy with architecture (as he taught astronomy at Oxford in 1661). The Jacobean style Wren used at Greenwich was less ornate and more conservative than past styles of architecture, as it was a mix of borrowed details from prior historic institutions and churches. Therefore, Wren's observatory, and his particular use of style and motifs, made it one of the first buildings to be closely associated with modern science. Ewart was influenced by Wren's seventeenth-century interpretation of a scientific modern institution, as Wren's observatory was globally well known for its prime meridian, a geographic coordinate system at which longitude is defined to be $0^{\circ}$ worldwide. ${ }^{8}$ Also, its location at Greenwich made it the centre of world time. ${ }^{9}$ Ewart knew this, crediting the example of this building of science with a distinct break away from past architectural styles, to that of a promising new one. Additionally, this was exactly what he hoped to achieve in the construction of a new Canada.

The relatively conservative style of Wren's observatory was what Ewart was looking for in the creation of the Dominion Observatory, as an institution that holds a similar role in Canada: this Observatory was to be the location of a national northern meridian line-with reference 


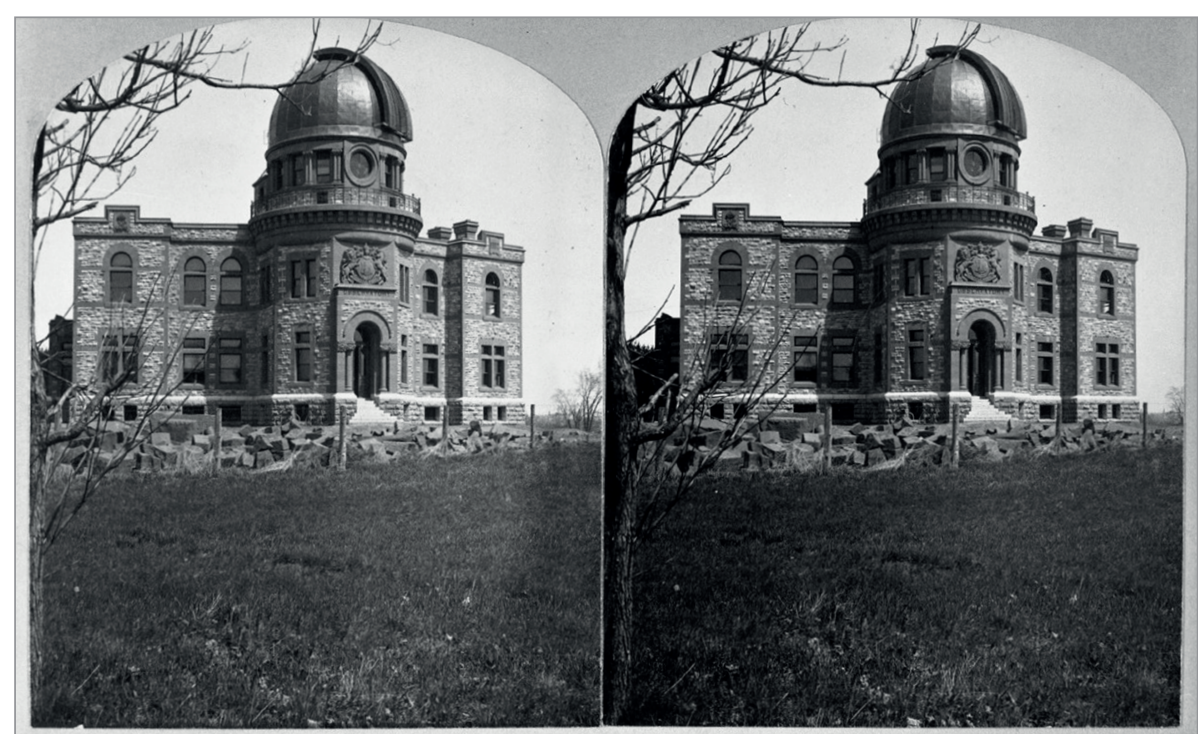

FIG. 3. DOMINION OBSERVATORY, OTTAWA, BY ARCHITECT DAVID EWART, STEREOGRAPHIC VIEW, C. 1904. | SLIDE 367, DOMINION OBSERVATORY COLLECTION, NATURAL RESOURCES CANADA ARCHIVES, EARTH SCIENCES DEPARTMENT.

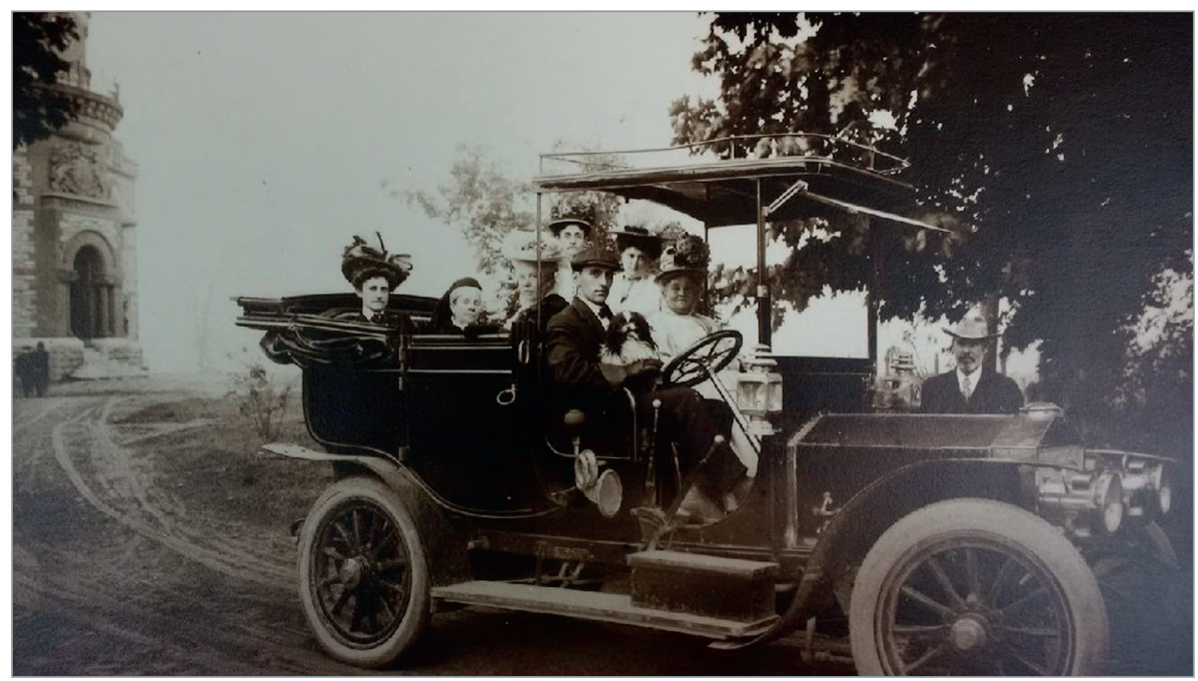

FIG. 4. PRIME MINISTER SIR WILFRED LAURIER'S WIFE LADY LAURIER AND FRIENDS AT DOMINION OBSERVATORY, 1905-1910.| DOMINION OBSERVATORY FONDS, BOX \#2, CANADIAN NATIONAL MUSEUM OF SCIENCE AND TECHNOLOGY ARCHIVES, OTTAWA, CANADA.

to Greenwich world time-called the Canadian Prime Meridian. ${ }^{10}$ However, Ewart did not want to copy Greenwich Observatory's architectural attributes directly, because he strived to give the architecture a visual image of greater independence from Britain for the first new National Canadian Observatory. At that time, Canadians strove for a greater degree of self-government, and therefore wanted to have a building style that would connote the perceived greatness of European visual cultural identity, yet with a new distinctly North American characteristic. This is something that Ewart continued to do across his projects in his role as Dominion architect in Ottawa from 1896 until 1914. His known examples are of the Royal Canadian Mint, the Dominion Archive, and the Victoria Memorial Building. This latter was originally built for the Geological Survey of Canada headquarters in 1911, which houses the Canadian Museum of Nature today.

Like his predecessors in this position, architects Thomas Seaton Scott and Thomas Fuller, Ewart chose to work with the Gothic Revival style, in many of his Canadian capital projects, albeit with a more Tudor or Baronial influence. This explains the use of the second final phase of Romanesque Revival style that he chose for his design of the Dominion Observatory. The "High" or "Late" Romanesque Revival that he employed may have also been influenced by earlier examples of this architectural style which already existed in Canada. An example of this is the well-known (and frequently published) University College building, at the University of Toronto, erected in 1856 by Cumberland and Storm architects. ${ }^{11}$

Ewart employed this visual architectural vocabulary to exemplify Canada as not just a commonwealth under Britain but also as a growing, increasingly independent colony. By implementing some ornamentation from medieval Romanesque cathedrals, he strived to instill a language of historic tradition into a newly built Canadian presence. This was meant to exert an innovative modern permanence with use of the past, while associating the construction of this National Observatory with the country's progress in science. For this reason, Ewart was likely influenced by the circle of architects led by American Henry Hobson Richardson, who similarly favoured this high style of architecture to meet the requirements for a new nation. ${ }^{12}$ The first phase of Romanesque Revival appeared in Canada during the 1840s, influenced by medieval twelfth-century 
architecture. This style of building was characterized by squared towers, hipped and gabled roofs, and other medieval detailing such as round-arched windows and wide voussoirs, which lend a heavy appearance.

Behind both the earliest cases of Canadian Romanesque Revival and later ones such as the Observatory, the core ideas were drawn from European medieval churches. However, for the late Romanesque Revival in Canada, the elaborate sculptural elements and heavily layered facades, for instance, were pared down to achieve a greater degree of simplicity, in order to modernize the design (fig. 5). This type of adaptation in the Romanesque Revival can be seen, for example, in the Dominion Observatory's windows; only the windows on the second floor are framed by a round-headed arch, whereas those on

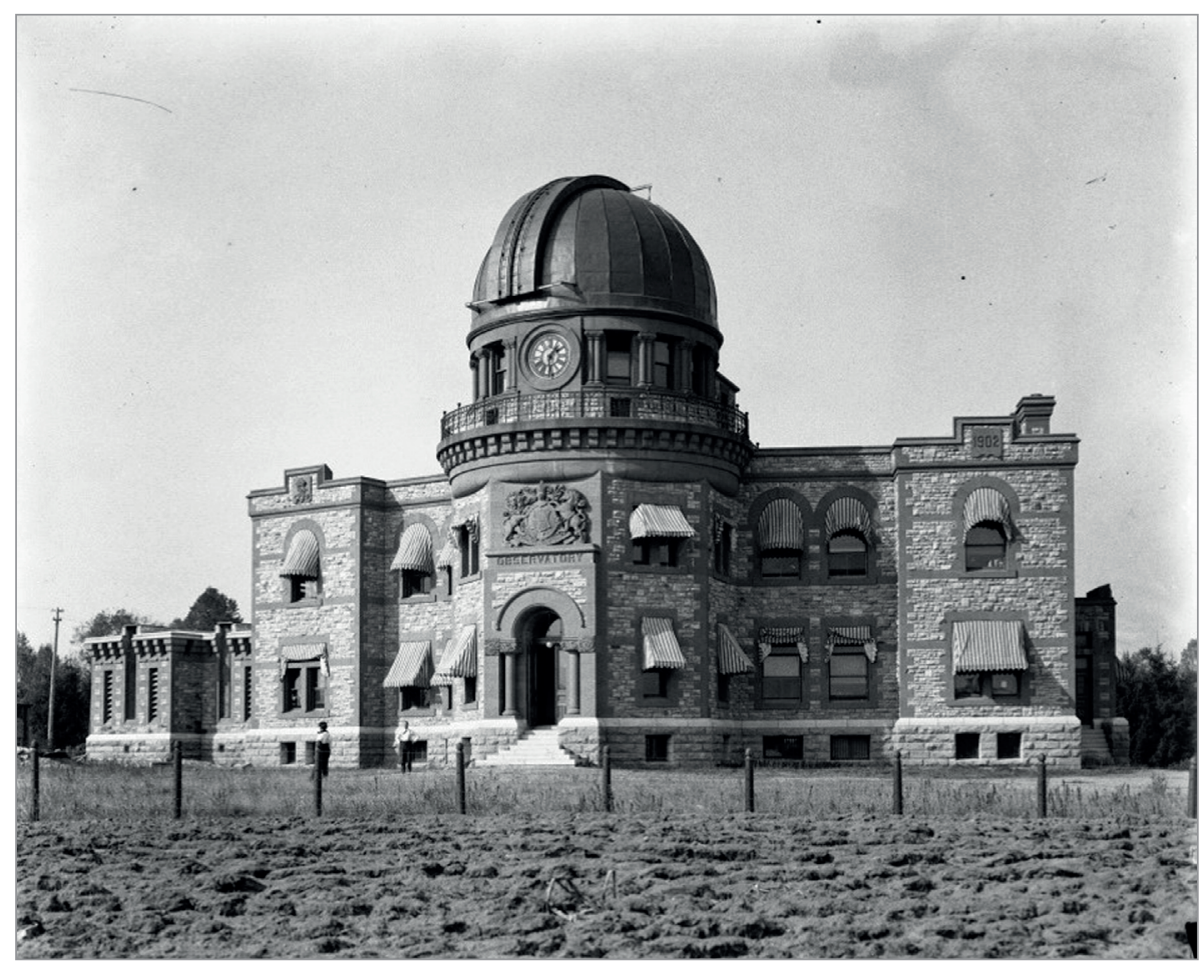

FIG. 5. DOMINION OBSERVATORY, OTTAWA CONSTRUCTION, FRONTAL VIEW, C. 1904. | SLIDE 311-3, DOMINION OBSERVATORY COLLECTION, NATURAL RESOURCES CANADA ARCHIVES, EARTH SCIENCES DEPARTMENT. the first floor are simply rectangular. This mimics, at least in part, the tall multi-storey arches of the medieval past, or what is considered to be a signifier of importance in historic Romanesque buildings, but simplifies and updates the whole in the contemporary setting of a newly formed country. The placement of the arches on the upper levels also serves as a useful architectural visual tool to bring the central metal domed roof, set high above the arched entry door, into focused view.

Richardsonian Romanesque Revival carried on these medieval motifs, introducing a second and more widely popular phase, lasting from the 1880 s through to the early twentieth century. These buildings were characterized by exteriors composed of rough-faced, robust masonry blocks. Additional features included heavy sculptural details, round-arched

windows, round-arched entrances with short polished columns, and prominent voussoirs set flush with walls. ${ }^{13}$ The Dominion Observatory was constructed in this second phase of Richardsonian Romanesque Revival, a freer manner that Ewart followed as an architectural trend in 1902. This popular architectural direction could also be seen employed in Canadian churches, university campuses, and civic institutions, as seen in James Lennox's design of Toronto City Hall in 1890, and the Toronto architectural firm Symon and Rae's Ontario Hall in 1902 at Queen's University, in Kingston, Ontario. The Richardsonian Romanesque Revival's visual language was thus applied in the creation of many new buildings in the Dominion, such as the Observatory, as seen in its characteristically large blocklike façade to give a sense of sturdy construction, permanency, and wealth of material. This was also done so that it could visually interpret the colony of Canada as a place of growth of industry toward independence.

Other Romanesque Revival features can be observed in the heavy castle-like, chiseled red sandstone walls, which not only exemplify the expense of these materials and the richness of colour, but also exude an important sense of nationbuilding with their solid appearance, serving as a reflection of the serious nature of the science held within. ${ }^{14}$ Ewart's challenge was to design a cultural institution with an understanding of science that also placed focus on Canada's specific pursuit of astronomy. When entering the building itself, the lintel makes this intent clear, as the engraved sign stating "OBSERVATORY" makes no mistake as to the purpose of that building. In addition, there are detailed stone-carved foliage ornaments and columns at each side of the main door, consisting of modified motifs in the Classical tradition, which 


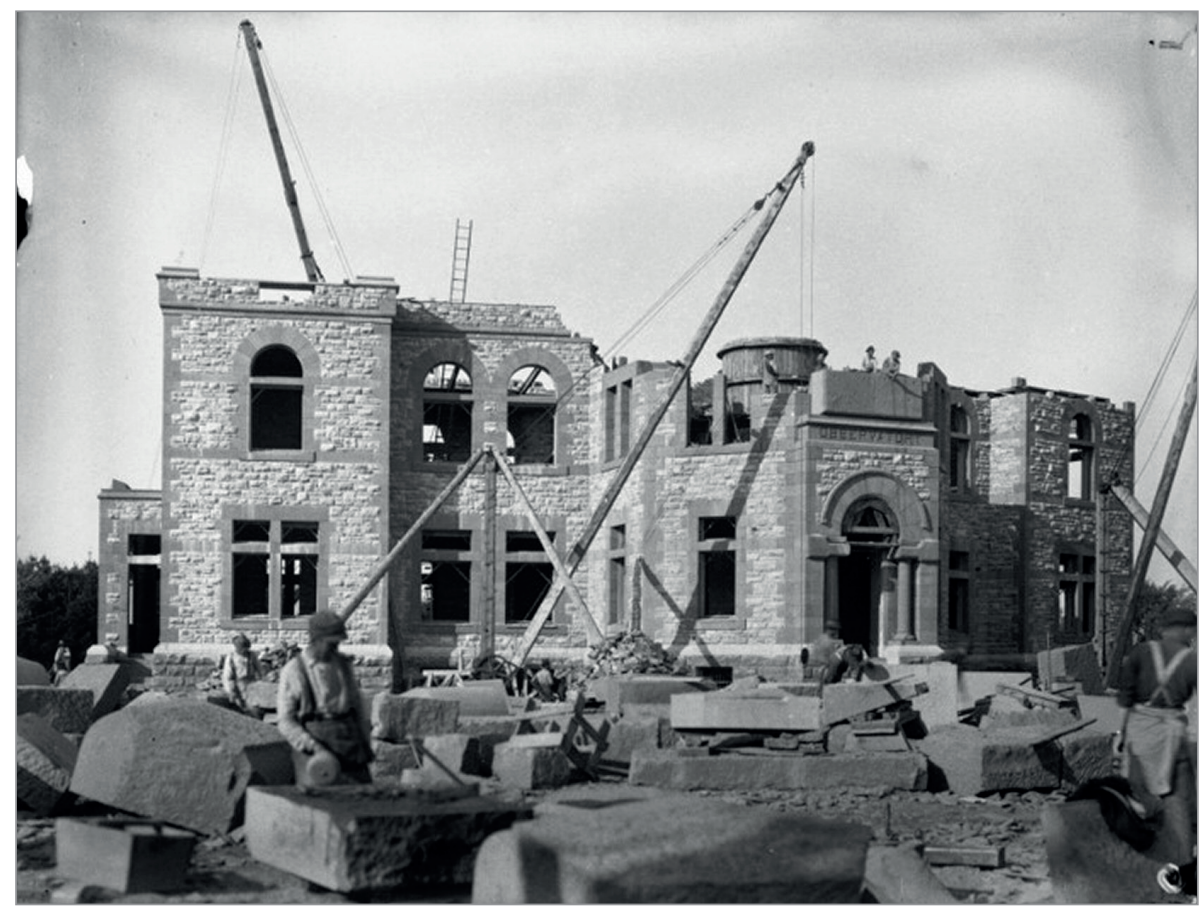

FIG. 6. DOMINION OBSERVATORY, OTTAWA CONSTRUCTION SITE, 1903-1904. | SLIDE 366, DOMINION OBSERVATORY COLLECTION, NATURAL RESOURCES CANADA, EARTH SCIENCES DEPARTMENT.

lend a formality to the entryway, as visual reminders of the history of astronomy in the Western tradition. These columns are not the rigid and precise Orders of Greek or Roman architecture, but are rather inspired by them (fig. 6).

\section{THE OBSERVATORY INTERIOR: DICTATED BY HEAD CANADIAN ASTRONOMICAL INSTRUMENTS}

The underground level reveals unfinished stone block walls that are pinkish in nature and quarried from Eastern Canada, adding to a continued sense of visible weight from the outside. Heavy marble stairs, and up to five-foot-thick windowsills lend an impression of solidity and expense. In the basement, the shape of the building was dictated by the work performed within and the instruments held inside. For example, the lowerlevel walls are curved in areas where the telescopic pier enters the ground, and this is where an office space called the wireless or clock room was located, in which transfer of time signals across Canada occurred. Above, the ground floor of the building was utilized the same way from 1905 to 1970 . In later years, it accommodated the addition of seismology, geomagnetism, and mapping staff. This main floor was divided into two wings, with the original tiled flooring that can still be seen

Moreover, on the ground floor, the most important section of the plan was the west wing, which contained the main seismograph and accommodated the space called the "transit house." Here, the Dominion Observatory is noted in history as being a nationally important part of science, because this is where Canada's famed reference meridian was placed. Although the Observatory and its meridian were constructed after the prime of Sir Sanford Fleming's career, it was built to continue his work on time zones and standard time. Also, the Dominion Observatory was built for positional astronomy, similar to the Greenwich Royal Observatory in England, and defines the prime meridian for Canada in a similar way. This North American meridian line's purpose was to create a baseline in order to establish the borders of the then new provinces of Alberta, Saskatchewan, and Manitoba. In addition to establishing standard time for the country, it led to the famous "One o'clock after the long dash" broadcast by the Canadian Broadcasting Corporation (CBC Radio). This occurred until this function was moved to the National Research Council in the 1970s, although work continued on astronomical research, along with the Department of Seismology's measurements to prove the theory of continental drift and other aspects of earth science, until the Observatory ceased operations. ${ }^{15}$ Presently, the reference meridian is commemorated with a plaque on the west façade in relation to a southern azimuth that stands a few hundred feet away.

At the centre of the main floor of the building is the front entry, called the rotunda for its inner, circular-shaped vestibule, where a wide central cylindrical observation pier can be seen. Here, the walls are surrounded by a 1958 ceiling mural by artist Juan Geuer, who was also the head draftsman for the Earth Physics Branch. This central pier served as a functional element above which the fifteen-inch retracting Dominion Telescope would sit. The pier was tall, stretching up to the third and fourth floors, while also being well anchored into the stable ground below. This is a crucial aspect of the architectural plan, in order to ensure the telescope's accuracy with measurements 


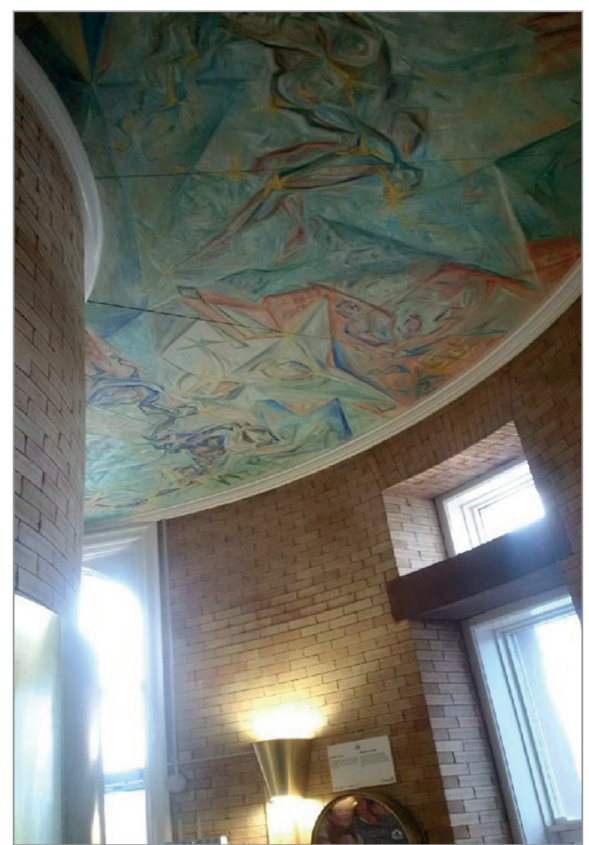

FIG. 7. FRONT ENTRY CEILING MURAL AROUND TELESCOPE PIER, C. 1958, BY JUAN GEUER, CANADIAN ARTIST AND PAST DOMINION OBSERVATORY LEAD DRAUGHTSMAN. | SHARON ODELL MARCH 7, 2017.

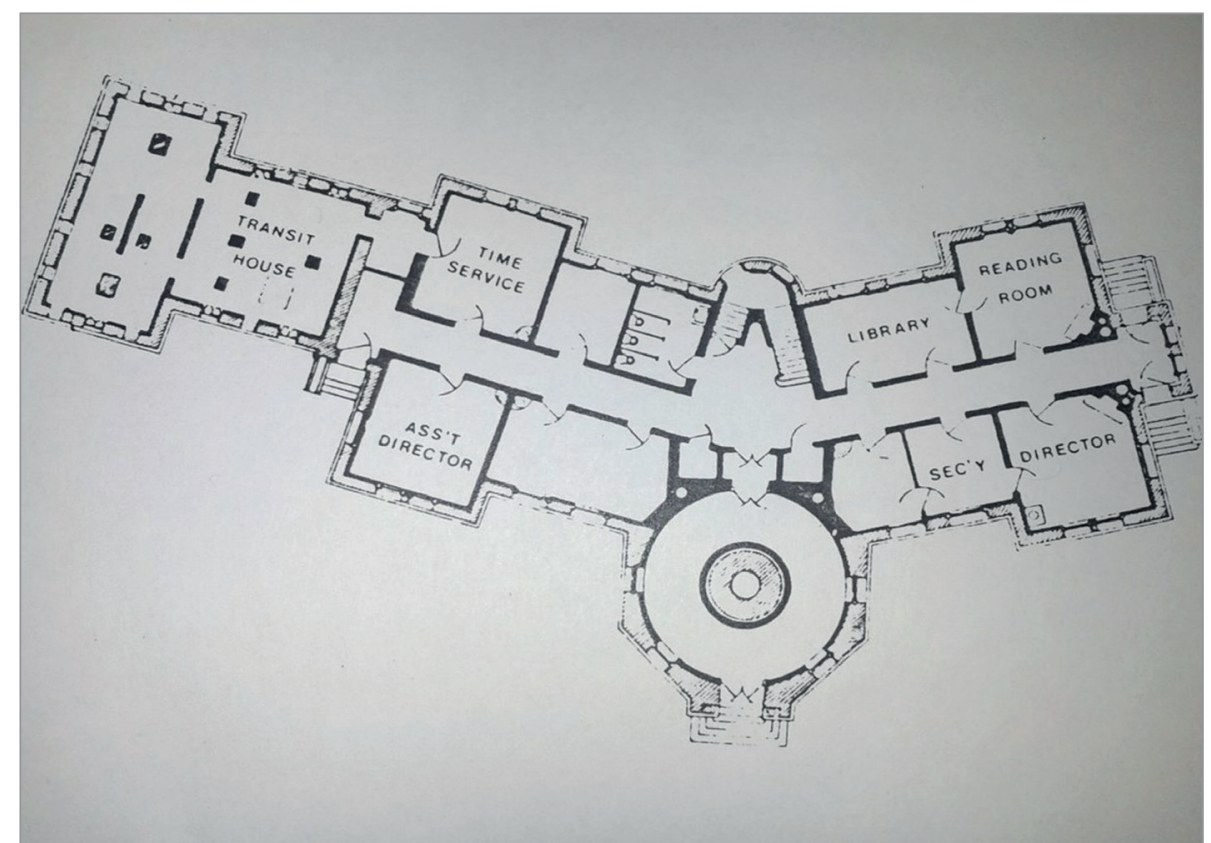

FIG. 8. MAIN FLOOR PLAN OF THE DOMINION OBSERVATORY, OTTAWA, CANADA, 1905-1970. | HODGSON, JOHN H., THE HEAVENS ABOVE AND THE EARTH BENEATH: A HISTORY OF THE DOMINION OBSERVATORIES: PART 1 TO 1946, OTTAWA, GEOLOGICAL SURVEY OF CANADA, VOL. 1, 1989, P. 26.

glass panes are strategically placed at the back of the building so as to not detract from the central Observatory dome's stately appearance from the front. This floor additionally houses an east wing, with two small "warm rooms" that would have held the electrical equipment for the telescope and astronomers. The fourth floor, or observation dome, was un-insulated as part of functional necessity. It also allowed the ribs of the dome and clockwork mechanisms for the roof opening to be visible. Called a "cold room," this space was designed to maintain the same temperature as the outside environment no matter the season. This requirement maintained the telescope's visual accuracy, with no fogging of the lens glass. In order to assist with the maintenance of outer and inner temperatures, the base of the round dome has window vents for increased air flow, and an outer balustrade that circles the foot of the dome, enabling access for repairs.
This dome was also designed to fit the fifteen-inch retractable telescope perfectly. In fact, the equipment dictated the overall architectural measurements of the Observatory, due to the Department of the Interior's need for precise coordinates and timekeeping. Therefore, the scale of equipment was important enough to be ordered prior to the Observatory's construction, allowing the fifteen-inch refracting telescope purchased in 1897 to directly influence the specific drafted plans of the given astronomer's observing space. These plans were also drawn in 1898 to accommodate the largest telescope in Canada at that time, requiring not only an impressive interior observation space, but additionally a functional one at a size of thirty feet. Part of the strategy proposed consisted of a wooden floating floor within the dome that astronomers could walk upon, as it was mounted to the outer walls, separate from the tall central pier where the telescope sat unhindered in order to capture natural light. These 


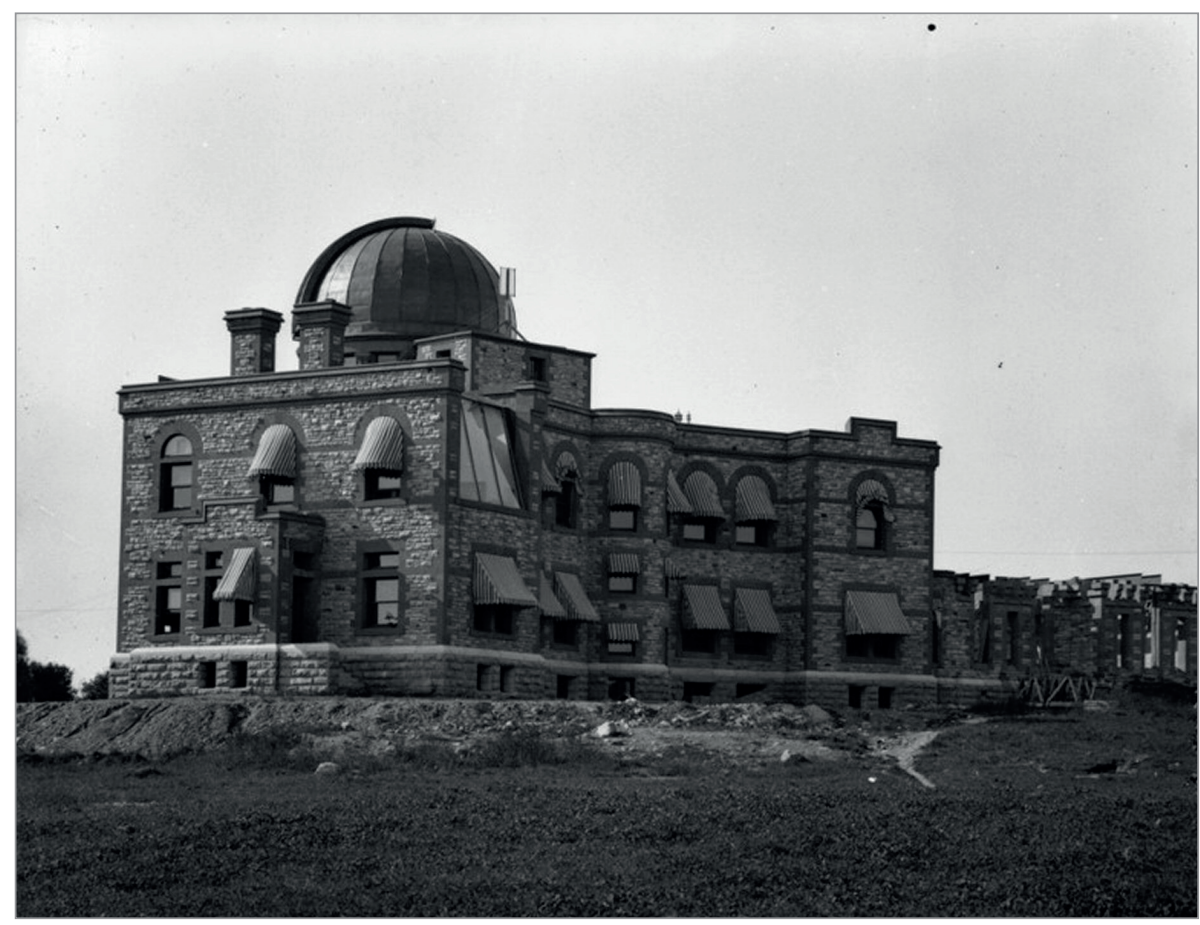

FIG. 9. DOMINION OBSERVATORY, OTTAWA, 1905-1913, REAR VIEW. | SLIDE 371, NATURAL RESOURCES CANADA ARCHIVE, EARTH SCIENCES DEPARTMENT.

from movement (fig. 9). Also, the dome is primarily where the workings of the astronomy program would happen within the Observatory. Its function was the leading science of the age and where Mary Grey, the last astronomer of that building's program, would carry out her daily research. Eventually, this would lead to her enthusiasm toward the continuation of the Observatory's architectural preservation, and for the historic telescopic equipment held within.

\section{THE LAST DOMINION OBSERVATORY ASTRONOMER: AN ENDURING LEGACY}

Grey conducted her research at the Dominion Observatory from around the mid-1950s until the astronomy program closed in 1970. Her professional projects conducted at the Observatory were primarily with the fifteen-inch refracting telescope. Similar to her predecessors at the Observatory, she provided a public education function. For example, Saturday evening stargazing at the Observatory was often offered to the public, for night sky viewings through the historic telescopic instruments, which would allow visitors to examine the inner architecture of the observation dome. When there was finally a call to close the Astronomy program at the Observatory in c. 1967, Grey wrote a series of articles in the Journal of the Royal Astronomical Society of Canada. In her texts, she described the ongoing astronomical research at the Observatory, regardless of its winding down of assignments within that discipline. This can be seen as a reflection of her endeavour to keep professional Canadian astronomy current, even if there was little time left to do so within an official national capacity at the Observatory. The first article on the Dominion Observatory was in
December of $1968,{ }^{16}$ shortly after the announcement that the program would close. Additionally, other articles were published in June 1969, December 1969, and a final one in June $1970 .{ }^{17}$ The timing of the last issue coincided with Grey's final year as an operating astronomer with the Dominion telescope. Following that, she would eventually voice her concern for the Observatory building's preservation, on the basis of its history for Canadian science. She believed it was a tool from which future generations could learn, and continued to advocate to that end.

When technological improvements allowed professional astronomers access to larger telescopes, it caused the Federal Government to transfer all astronomy activities from the Dominion Observatory to the National Research Council of Canada in 1970. After that year, public education became the only function that the Observatory served with respect to astronomy, given its nationally significant architecture and its connection to historic Canadian astronomy equipment. However, educational programs at the Observatory finally ceased, when public access to the dome and fifteen-inch telescope became a fire code violation. At that time, with no official astronomy function to facilitate public education, the telescopes of the Dominion Observatory were at a standstill; that is, until Grey made an unprecedented and controversial decision in the fall of 1974, when the fifteen-inch telescope was removed and placed under her stewardship in her new role as curator of physical sciences at the National Science and Technology Museum in Ottawa.

\section{THE DOMINION TELESCOPE: HEART OF THE OBSERVATORY}

The Science and Technology Museum's acquisition of the Dominion Telescope, the solar telescope, and the transept 


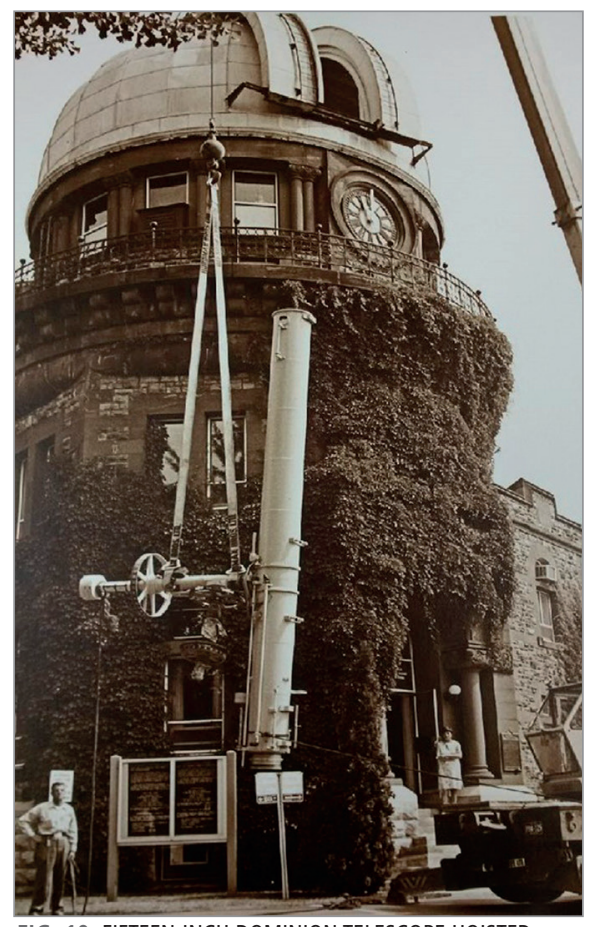

FIG. 10. FIFTEEN-INCH DOMINION TELESCOPE HOISTED FROM THE DOME OF THE DOMINION OBSERVATORY FOR TRANSFER TO CANADIAN SCIENCE AND TECHNOLOGY MUSEUM (CSTM), 1974. | DOMINION OBSERVATORY FONDS, BOX \#2, CANADA MUSEUM OF SCIENCE AND TECHNOLOGY ARCHIVES, OTTAWA, CANADA.

equatorial telescope would in turn leave the Observatory architecture on its own (fig. 10). At that time, Grey continued to work at the museum while holding various membership positions within the Ottawa Centre of the Royal Astronomical Society of Canada (RASC), from 1964 until her passing in 1996. She chaired the national Committee on Publications and in the RASC Journal she wrote notes on the Dominion Observatory once again. However, now her subject matter was focused mainly on the Dominion Telescope, which then was used as a heritage link back to the Observatory itself; a building that remained in a state of limbo, as long as it was missing the important artifacts that it was created to house. ${ }^{18}$ Grey realized this conundrum too, and although she rescued the telescopes from the Observatory, at the museum she continued nonetheless to teach the history of the building. She achieved this through educating the public about Canadian astronomy and through current astronomical events in Canada that could direct back to the Dominion Observatory. She raised public interest for this subject matter through radio broadcasting and writing newspaper columns in the Ottawa Citizen and Science and Technology Museum's quarterly, titled Star Gazing, as well as in astronomy journals such as $S k y$ News. Grey's interest in the history and heritage of the Dominion Observatory and the related telescopes was likewise very evident in her research talks on the history of the architecture, and the social fabric that tied these constellations of history together. This example of her efforts to preserve the meaningful information behind the Dominion Observatory's past and present architectural existence could be seen in her installation at the museum. An education-based observatory was constructed under Grey's instruction, so that the fifteen-inch telescope could be operational once again. Large poster-size images of the Dominion Observatory building were placed around the interior of this make-shift viewing dome as well, to link the Dominion Telescope back to its original site.

Additionally, in October 1985, Grey wrote an article in the Journal for Royal Astronomical Society, titled "Astronomy activities at the National Museum of Science and Technology." This article was written ten years after her last article on the Dominion Observatory in the same journal, bridging the gap between the function of the Dominion Telescope as a museum artifact to its original operations, in order to function as a window to the past that would hopefully link to the existence of the Observatory itself at its original Ottawa location.
The Canada Science and Technology Observatory building, which opened January 15, 1975, was eventually dedicated to Helen Sawyer Hogg in 1989. This dedication was due to Grey's promotion of the idea that both Sawyer Hogg-a first recognized Canadian woman astronomer and scientist in her own rightand the Dominion Observatory where the first Canadian government astronomy program was held-were both worthy of celebration on a historic national level. ${ }^{19}$ The acknowledgement also given to Hogg Sawyer was in part for Grey to promote astronomy at the museum, as her contributions to this facet of science by that time were world renowned. Moreover, for this same accomplishment Grey received the Civil Service Association of Canada's prestigious Merit Award that same year (figs. 11 and 12)..$^{20}$

\section{THE OBSERVATORY CAMPUS LANDSCAPE: CONTINUAL CALL FOR CANADIAN SCIENTIFIC HERITAGE}

The Sawyer Hogg Observatory continued to play host to over thirty years of public viewing sessions with the Dominion Telescope. Unfortunately, this building was dismantled in December 2016, as part of the new museum renovations scheduled for the 2017 re-opening. Presently, the fifteen-inch telescope is in storage with an indefinite date as to when it will return to educational display or use again. However, the absence of such a historically significant telescope only further emphasizes the extent of Grey's remarkable influence on the reaches of Canadian astronomy. Her work in astronomy, combined with her teaching to the public about the history of the astronomy program at the Dominion Observatory, motivated other pioneering women astronomers in that field. This educational role became for her more imperative after the 


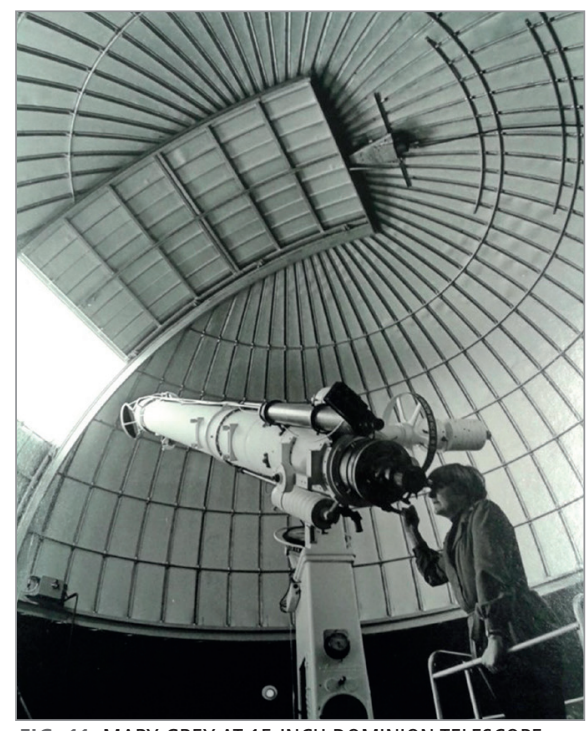

FIG. 11. MARY GREY AT 15-INCH DOMINION TELESCOPE WITHIN HELEN SAWYER HOGG OBSERVATORY,

C. 1980. | DOMINION OBSERVATORY FONDS, BOX \#2, CANADIAN MUSEUM OF SCIENCE AND TECHNOLOGY ARCHIVES, OTTAWA, CANADA.

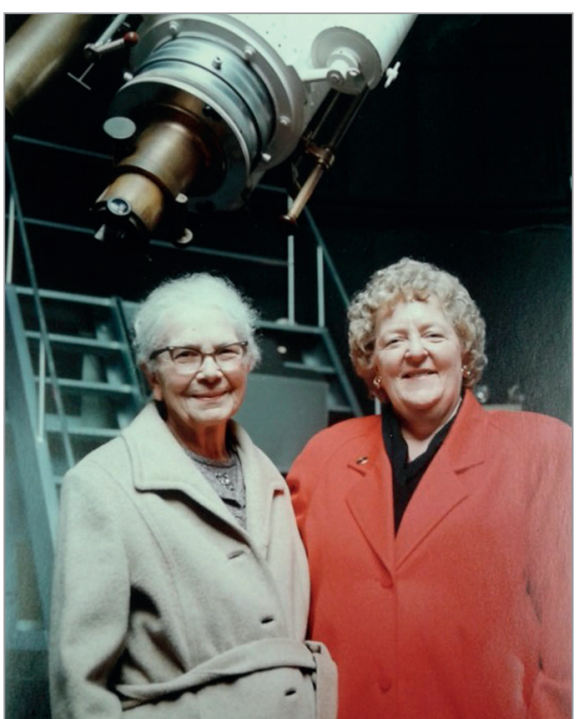

FIG. 12. MARY GREY (L) AND HELEN SAWYER HOGG (R), BESIDE THE 15-INCH DOMINION TELESCOPE AT THE HELEN SAWYER HOGG OBSERVATORY, 1989. | DOMINION OBSERVATORY FONDS, BOX \#2, CANADIAN MUSEUM OF SCIENCE AND TECHNOLOGY ARCHIVES, OTTAWA, CANADA.

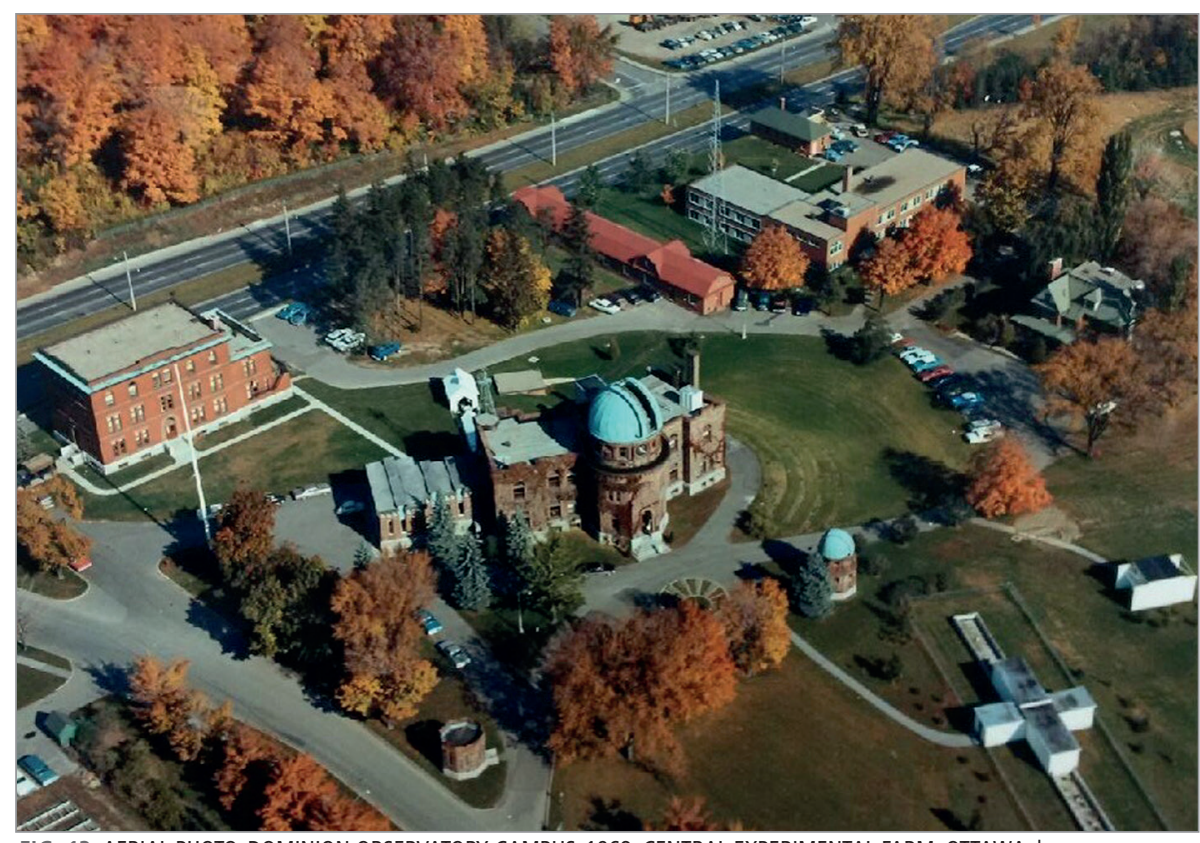

FIG. 13. AERIAL PHOTO, DOMINION OBSERVATORY CAMPUS, 1968, CENTRAL EXPERIMENTAL FARM, OTTAWA. | DOMINION OBSERVATORY FONDS, BOX \#2, CANADIAN MUSEUM OF SCIENCE AND TECHNOLOGY ARCHIVES, OTTAWA, CANADA. retirement of Miriam Burland, who was Grey's own mentor, as public relations officer in 1961. Grey further achieved this educational outreach through her own research on astronomical findings at the Observatory, and also by interacting on both local and national levels to disseminate this history. Grey accomplished this while publishing more material as a member of the Royal Astronomical Society of Canada, and while she was national president and she did it all while advocating for the architecture and tools of her trade, in a vouch to continue their preservation.

These pieces of knowledge instilled in Grey were exported into tours conducted to the public concerning the interior inner workings of the Dominion Observatory from about 1960 to $1970 .{ }^{21}$ In her later life at the museum, she also continued to teach and advocate. However, as great as the museum was in carrying on this legacy, the architecture of the Dominion Observatory should still be thought of as key to possible future tours in its historic context. This is especially felt now by astronomy interest groups after the loss of the Sawyer Hogg Observatory, but also because of the Dominion Observatory's unparalleled value to its related telescopic artifacts, through its historic Observatory campus landscape. ${ }^{22}$

Grey's passion demonstrates the extraordinary qualities of the Dominion Observatory, and its related campus buildings, in its capacity of housing historic scientific research for the nation. Her motivation to preserve this architecture is a reminder of Ewart's original intended design. The solid and grand Romanesque Revival style used in the Observatory's construction was specifically chosen to represent the importance of Canada's scientific pursuits, and to underline the permanency and nationalism of a young 
country with great promise. By bringing attention to this, Grey also referenced the sciences of astronomy, seismology, and geo-magnetism as not simply important areas of research contained within the Observatory, but also as means of strengthening Canada's independence from Britain. Thus, returning to the symbolism of the Dominion Observatory, as expressed in its striking architecture, the building was of equal importance to Canada as the scientific research that it contained.

As Grey did in the past, many presently believe that it should continue to be protected for these reasons at both local and national levels, and recognized as a historic landmark of the North American prime meridian that many active astronomers today are calling to have celebrated. ${ }^{23}$ There is, however, still further work needed to ensure its protection, along with the related outer buildings that comprise the Dominion Observatory campus as a whole. There is new cause for concern, with the recent transfer of Central Experimental lands to the Ottawa Civic Hospital in May of 2018, which continues to be politically discussed today. ${ }^{24}$

When the Dominion Observatory's science of astronomy and its public education discourse moved to the museum in 1974, it pushed public knowledge of what used to be a telescope and a building that were utilized in tandem, to that of separately located artifacts with a tenuous link to the combined history they once had. This Observatory and its related campus of buildings only remain important now from an outside perspective; as a historical example of high architectural style of the Romanesque Revival. Here, the astronomical connotations are only alluded to through the central domed roof, still seen presently in person. Instead of what used to be an engaging, public educational centre that promoted Canada's finest achievements in astronomy, the Dominion Observatory is now used as another branch of Natural Resources Canada (NRCAN), un-related to the field. This building once shared an abundant amount of knowledge with the public and was built to disseminate that research. As mentioned earlier, many believe the key now for this building to continue its educational value is to strengthen its scientific heritage designation, by following the same principles that Grey laid out; namely, her public outreach and call for preservation of the observatory campus as a whole. For, without all parts of this story, only a fragmented lesson in Canada's history of astronomy will be known otherwise to future generations.

We must ask ourselves: how does the Observatory remain important presently? After all, the label of "National Dominion Observatory" meant that it was the epicentre of the subject and study of astronomy in this country. Then again, without the intervention of Mary Grey, one must wonder how the history of Canadian astronomy and the architecture of the Dominion Observatory might read now. This Observatory still stands today in almost the exact appearance that it did over one hundred and seventeen years ago. However, its future and Grey's legacy are dependent upon our action to form a new strategy for its preservation.

\section{NOTES}

1. Hodgson, John H. The Heavens Above and the Earth Beneath: A History of the Dominion Observatories. Part 1: To 1946, Ottawa, Energy Mines and Resources Canada, Geological Survey of Canada; Hodgson, John H. The Heavens Above and the Earth Beneath: A History of the Dominion Observatories. Part 2: 1946-1970, Ottawa, Energy Mines and Resources Canada, Geological Survey of Canada.
2. Odell, Sharon, February 2017, Interview with Timothy Cole, president of Ottawa RASC: "Mary Grey had an honorary doctorate based on her self-taught expertise and scientific contributions to Canada, she did not attend official graduate studies."

3. Broughton, R. Peter, 2003, "Mary Grey," in Looking Up: A History of the Royal Astronomical Society of Canada, Toronto, Toronto University Press, p. 127.

4. Natural Resources Canada, 2015, "100 Years of Geodetic Survey's in Canada," Government of Canada, November 25, [http://www.nrcan. gc.ca/earth-sciences/geomatics/geodetic-reference-systems/canadian-spatial-reference-system/9110], accessed October 31, 2019.

5. Broughton, "Mary Grey," op. cit., p. 127.

6. Brooks, Randall and Calvin Klatt, 2005, "The Dominion Observatory - 100 ${ }^{\text {th }}$ Anniversary," National Research Council of Canada (NRCAN), [https://www.casca.ca/ecass/issues/2005-me/ features/brooks/e-Cassi DomObsV4.htm], accessed November 9. 2016.

7. Jarrell, Richard A., 1991, "The Origins of the Dominion Observatory, Ottawa," Journal for the History of Astronomy, vol. xxii, no. 1, p. 45.

8. Devoy, Louise, 2019 [rev. ed.], "The Story of the Greenwich Meridian," in $0000^{\prime} 00$ " On the Line, Gomer Press, UK, Royal Observatory Greenwich, p. 8.

9. Royal Museums Greenwich, 2020, "Royal Observatory: What Is the Prime Meridian and Why Is it in Greenwich?" [https://www. rmg.co.uk/discover/explore/prime-meridiangreenwich], accessed July 6, 2020.

10. Waymarking.com "Canadian PrimeMeridian," [https://www.waymarking.com/waymarks/ WMDEFP Canadian Prime Meridian], accessed July 1, 2020.

11. Maitland, Leslie, Shannon Ricketts, and Jacqueline Hucker, 1992 [2 ${ }^{\text {nd }}$ ed., 2004], "The Romanesque Revival Style," in A Guide to Canadian Architectural Styles, Peterborough, Broadview Press Ltd., p. 85.

12. Id., p. 93-110.

13. Id., p. 84

14. Ontario Architecture, n.d., "Building Styles: Romanesque Revival (1840-1900)," [http:// www.ontarioarchitecture.com/romanesque. htm], accessed November 6, 2016.

15. Odell, Sharon, March 2020, Interview with Douglas O'Brien, member of Ottawa RASC: "The Dominion Observatory has significant historical value as it was built for positional 
astronomy like the Royal Observatory in Greenwich."

16. Grey, Mary W., 1968, "Dominion Observatory, Ottawa, Ontario," Journal of the Royal Astronomical Society, vol. 62, December, p. 383-385.

17. Grey, Mary W., 1970, "Dominion Observatory, Ottawa, Ontario," Journal of the Royal Astronomical Society, vol. 64, June, p. 174-176.

18. Royal Astronomical Society of Canada, 1996, "Honour Role: Mary Grey: RASC Service Award to Grey, Mary, Journal of the Royal Astronomical Society of Canada (JRASC), December 1990," vol. 84, no. 7, [], accessed September 20, 2020.

19. Mary Grey Fonds, Canadian Museum of Science and Technology Archives (CASM), accessed May 3, 2019.

20. Royal Astronomical Society of Canada, "Honour Role: Mary Grey," op. cit.

21. Mary Grey Fonds, CASM Archives, op. cit.

22. Wolfson, Michael, 2019, "Ottawa, let's share and celebrate the Dominion Observatory, Ottawa Citizen," 23 January [https:// ottawacitizen.com/opinion/columnists/ wolfson-ottawa-lets-share-and-celebratethe-dominion-observatory] accessed August 13, 2020.

23. Moreau, Robert, 2020, "L'Observatoire fédéral, le Greenwich du Canada," Heritage Ottawa Newsletter, vol. 47, no.1. p.6.

24. Maitland, Leslie, 2020, "Update on the Central Experimental Farm National Historic Site: Community Engagement Group (CEG)," Heritage Ottawa Newsletter, vol.47, no.1. p.4-5. 